Volume 9. No. 2, February 2021

International Journal of Emerging Trends in Engineering Research

Available Online at http://www.warse.org/IJETER/static/pdf/file/ijeter08922021.pdf

https://doi.org/10.30534/ijeter/2021/08922021

\title{
Model of a Company Competitiveness Control by Means of Artificial Intelligence Tools
}

\author{
Sergii Stetsenko ${ }^{1}$, Lesya Sorokina ${ }^{2}$, Kateryna Izmailova ${ }^{3}$, Olha Bielienkova ${ }^{4}$, \\ Viktoriya Tytok ${ }^{5}$, Olena Emelianova ${ }^{6}$ \\ ${ }^{1}$ Department of Construction Economics, Kyiv National University of Construction and Architecture, Kyiv, \\ Ukraine, ssp241958@gmail.com \\ ${ }^{2}$ Department of Construction Economics, Kyiv National University of Construction and Architecture, Kyiv, \\ Ukraine, x_lyu_lyu@ukr.net \\ ${ }^{3}$ Department of Construction Economics, Kyiv National University of Construction and Architecture, Kyiv, \\ Ukraine, staskat@ukr.net \\ ${ }^{4}$ Department of Construction Economics, Kyiv National University of Construction and Architecture, Kyiv, \\ Ukraine, obelenkova@ukr.net \\ ${ }^{5}$ Department of Construction Economics, Kyiv National University of Construction and Architecture, Kyiv, \\ Ukraine, victoriatytok@gmail.com \\ ${ }^{6}$ Department of Construction Organization and Management, Kyiv National University of Construction and \\ Architecture, Kyiv, Ukraine, mkelena1@ukr.net
}

\begin{abstract}
This article is devoted to the problem of introduction of artificial intelligence systems into the activity of building participants and other building projects stakeholders. An example of determination of a contractor inner potential by means of fuzzy sets is presented. It is recommended to contracting companies to accumulate information about the components of the competitiveness potential, specifically about: their activity diversification (concentration), resource efficiency (sales volume to company assets quotient), pricing policy flexibility (level of discounts at tenders), business reputation level - business assurance level of a company (percentage of works executed and paid under the won tenders in the total value of the won tenders). A model of determination of the influence of the indicated parameters onto the portion of the won tenders in the total value of the submitted tenders, which is based on fuzzy logic, is offered. Creation of an information system, which is presented in the form of a database, which accumulates information during the whole lifecycle of a company, is the following research direction.
\end{abstract}

Key words: building company, building project, competitiveness, decision-taking systems, fuzzy logic means.

\section{INTRODUCTION}

Nowadays advantages in competitive struggle do not depend very much on the sizes and resource provision of specific companies, because the scope and the level of mastering of information resources [1], knowledge, intellectual and digital components of development [2] come to the foreground.

Building companies also actively introduce new software, decision-support tools and methods, artificial intelligence tools into their work. A series of scientific works is devoted to the issues of arrangement, designing, development and application of the systems, destined to process information, which are based on application of artificial intelligence methods. But the issues of application of the mentioned means in formation of anticrisis potential [3], economic immunity [4], development of building company management systems [5, 6], investment and building processes [7, 8], building organization and technology projects [9-12], inner and outer business processes of building stakeholders [13-15] stay of current interest.

The contemporary building development stage requires not only introduction of digital technologies, but compatibility of software and data transmission formats within the scopes of interaction of the main building stakeholders as well from the participants of building. Further research and development are required within the scopes of interdisciplinary interaction of the systems of taking and support of managerial decisions, oriented at complex research of the building projects stakeholders' competitiveness. Such systems have been created already for development companies [5, 6], but new methods of their utilization and search of new spheres of application are required, for example development of such systems for contractual building companies, which have differences from other participants of building. 
Sergii Stetsenko et al., International Journal of Emerging Trends in Engineering Research, 9(2), February 2021, $60-65$

\section{THE MAIN RESEARCH}

It is proposed to determine the portion of the won tenders in the total number (value) of the submitted tenders as the integral indicator of the contractor's competitiveness inner potential (CIP), which mediately points at growth or diminution of the competitiveness potential of a building company $(y)$. Depending on the direction of a change during a specific period, specifically: a month, a quarter, a year or, even, several years, " $y$ " value can acquire the values of "diminution of the competitiveness inner potential", "absence of development of the competitiveness inner potential" or "growth of the competitiveness inner potential". The initial data were received from the results of analysis of the activity and results of the following contracting companies at tenders on building works on Prozorro platform. The indicators of 19 contracting companies, the main spheres of activity of whom are general building works and road building, were studied.

It is assumed, that the potential competitiveness of a contractor " $y$ " is formed as a result of action of the following most important factors:

$x_{1}-$ diversification (concentration) of activity. The necessity of research and the importance of influence of this factor onto the competitiveness of companies is underlined in the works $[1,3,7]$. In this research diversification is defined as a quotient of the existing licenses for various activities of the building company to the average number of the existing licenses of the sample. Two states of the activities are proposed: "diversified activity" - the quotient is bigger than unity, "concentrated activity" - the indicator is smaller or equal to unity;

$x_{2}-$ resource efficiency. This indicator accumulates data about the effectiveness of utilization by the contracting company of the material and technical and labour resources. It is calculated as a quotient of the proceeds from sales to the assets value. It indicates the ability of the company to use material and technical resources, accomplish management of personnel, build relations with suppliers of building materials and structures and with other contracting and subcontracting (if a company is the general contractor) companies, optimize the quantity of its own building machines and mechanisms, and the quantity of workers on sites;

$x_{3}$ - pricing policy flexibility. This indicator is calculated on the basis of the results of the held tenders by the companies being analyzed for the respective year. If the data for a year in the base were absent, the indicator was established on the basis of data interpolation or extrapolation. It is calculated as the average percentage of the tenders, in which the company is the winner, of the tender offer of this company to the initial price at a specific competition;

$x_{4}$ - business reputation level - business assurance level of a company. It is calculated as percentage of the value of the contracts, executed by a company (and received payments) during a respective year, in relation to the value of the won tenders. This indicator characterizes the reputation of a contractor, its ability to execute works on time and with good quality, the actual adherence to the conditions, stated at a tender, and so on, but at the same time the business assurance of a contractor, which depends on the outer environment too. A portion of the contracts can stay unaccomplished not through the fault of a contractor, but because of absence of financing or causes, which depend on the customer of the building, not on the contracting company. Therefore the double name of the indicator is justifiable, taking into consideration its dual nature.

The sample of case 101 was studied.

A system of fuzzy logic conclusion by means of the Matlab Fuzzy Logic Toolbox applied programmes package using Sugeno type fuzzy conclusion system. A Sugeno-type system is a result of designing and teaching of a neuro-fuzzy hybrid model.

Method "hibrid" with the error level 0 and the quantity of cycles 30 was chosen for teaching of the hybrid network. As a result of teaching of the network, the error is 0.096 percentage points, which is enough for diagnosing of the competitiveness potential.

For the $x_{1}-x_{4}$ input factors and the resulting $y$ we receive "four inputs-one output" model (figure 1).

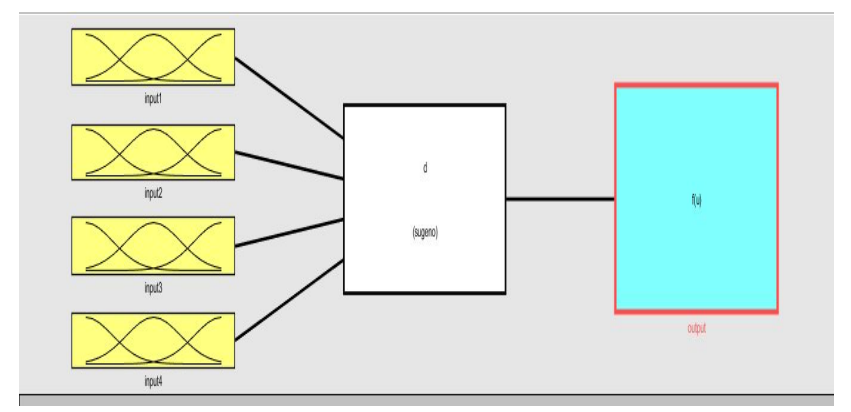

Figure 1: Model of influence of the $\mathrm{x}_{1}-\mathrm{x}_{4}$ factors onto the competitiveness potential of a contractor

Using the input variables membership functions fuzzification is accomplished, that is transition from numerical parameters of the input variables to fuzzy values of linguistic variables, that is, using the membership function for the terms of variables $x_{1} \_x_{4}$, which allow to determine its fuzzy set membership degree for any value of the input data row, while three membership functions of type gaus $2 \mathrm{mf}$ (double Gaussian function), which sets a combination of membership functions in the form of a combination of Gaussian curves and has the following form [4], are set for both input variables:

if $b_{1}<b_{2}$ them

$$
\mu(x)=\left\{\begin{array}{l}
\exp \left(\left(\mathrm{x}-\mathrm{b}_{1}\right)^{2} /\left(-2 c_{1}^{2}\right)\right), x<\mathrm{b}_{1} ; \\
1, \mathrm{~b}_{1} \leq x \leq b_{2} ; \\
\exp \left(\left(\mathrm{x}-\mathrm{b}_{2}\right)^{2} /\left(-2 \mathrm{c}_{2}^{2}\right)\right), \mathrm{x}>\mathrm{b}_{2} .
\end{array}\right.
$$

if $b_{1}>b_{2}$ them

$$
\mu(x)=\left\{\begin{array}{l}
\exp \left(\left(\mathrm{x}-\mathrm{b}_{1}\right)^{2} /\left(-2 c_{1}^{2}\right)\right), x<\mathrm{b}_{2} ; \\
\exp \left(\left(\mathrm{x}-\mathrm{b}_{1}\right)^{2} /\left(-2 \mathrm{c}_{1}^{2}\right) \exp \left(\mathrm{x}-\mathrm{b}_{2}\right)^{2} /\left(-2 \mathrm{c}_{2}^{2}\right)\right), \mathrm{b}_{2} \leq x \leq b_{1} ; \\
\exp \left(\left(\mathrm{x}-\mathrm{b}_{2}\right)^{2} /\left(-2 \mathrm{c}_{2}^{2}\right)\right), \mathrm{x}>\mathrm{b}_{1} .
\end{array}\right.
$$

where $\mu(x)$ - degree of membership of $\mathrm{x}$ in any fuzzy set; if $b_{1}<b_{2}$

$b_{1}$ and $b_{2}-$ lower and upper limits of the fuzzy set kernel; 
$c_{1}$ and $c_{2}-$ concentration coefficient of the left and right branches of the membership function curve.

if $b_{1}>b_{2}$ then the fuzzy set turns out to be subnormal.

Gaussian membership functions for "concentrated activities" and "diversified activities" of a contractor are presented on the curves (figure $2 \mathrm{a}-\mathrm{b}$ ). As it can be seen on figure 4 , the activity diversification degree had values from 0 to 3.9 among the analyzed contracting companies.

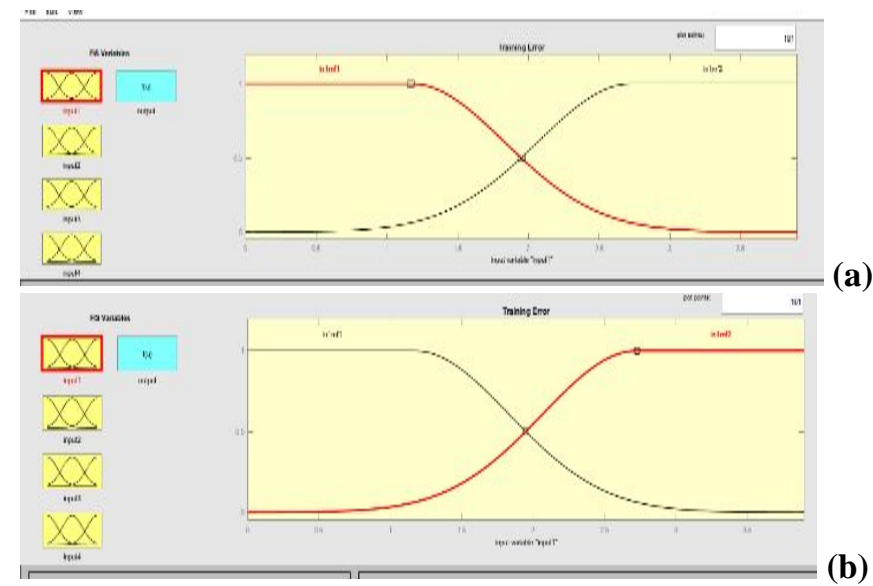

Figure 2: Double Gaussian membership functions of $x_{1}$ "activities concentration level" after introduction of the parameters for "concentrated activities" (a) and "diversified activities" (b) terms

According to the curves, presented on figure $2 a-b$, the level of assurance as for the activities concentration level is maximal in case, if the index value is less than 1,17 , because parameter $b_{2}=1,17$. That is, those contractors, who have specific quantity of existing licences for various activities for a specific period, have a high concentration level. Those companies, whose level of licences exceeds the average value by 2,73 times, have a low concentration level or a high diversification level.

Membership functions formulae are not written in evident form on figure 2 a-b. Instead, for the goal of making perception of the intermediate stages of a fuzzy logical conclusion easy, a concise record of the parameters of the functions, which are indicated for gauss $2 \mathrm{mf}$ type as an arranged set of three numbers, is given: [c1 b1 c2 b2]. According to the programme syntax of the environment, certain elements of the set are separated by means of spaces, in particular: the membership function of "concentrated

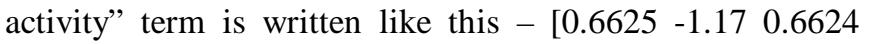
1.17], of "diversified activity" term like this $-\left[\begin{array}{ll}0.6632 .73 & 0\end{array}\right.$ $0.6625 .07]$.

Therefore if the building activities index has a value less than 1.17 , a company belongs indisputably to "concentrate activity" term for $\mathrm{x}_{1}$ factor:

$$
\begin{gathered}
\mu_{\text {conc }}\left(x_{1}\right)=\left\{\begin{array}{c}
e^{-\frac{1}{2}\left(\frac{x_{1}-1,17}{0,66}\right)^{2}}, \text { if } x_{1} \geq 1,17 \\
1, \text { if } x_{1}<1,17
\end{array}\right. \\
\mu_{\text {div }}\left(x_{1}\right)=\left\{\begin{array}{c}
e^{-\frac{1}{2}\left(\frac{x_{1}-2,73}{0,663}\right)^{2}}, \text { if } x_{1} \leq 2,73 \\
1, \text { if } x_{1}>2,73
\end{array}\right.
\end{gathered}
$$

Membership functions for "low resource efficiency level", "average resource efficiency level" and "high resource efficiency level" are presented on the curve (figure 3 a-c). As one can see on figure 3 , the quotient of proceeds from sale of products, works and services to assets of the companies analyzed made up from 0,1 to 2,5 times.

A resource efficiency level less than 0,4595 is considered low, because parameter $\mathrm{B}_{1}=0,4595$. That is those contractors, who have failed to achieve $0.46 \mathrm{UAH}$ of net income per 1 thousand assets, work inefficiently. The average level of resource efficiency is from 0,93 to $1,66 \mathrm{UAH}$ per 1 thousand assets of companies, and the indisputably high - 2,15 UAH per 1 thousand assets.

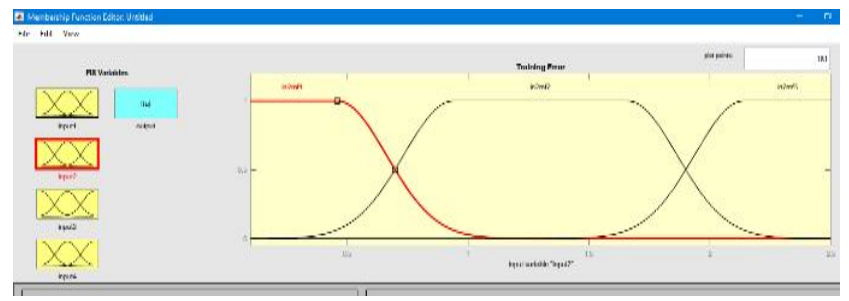

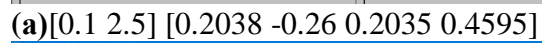

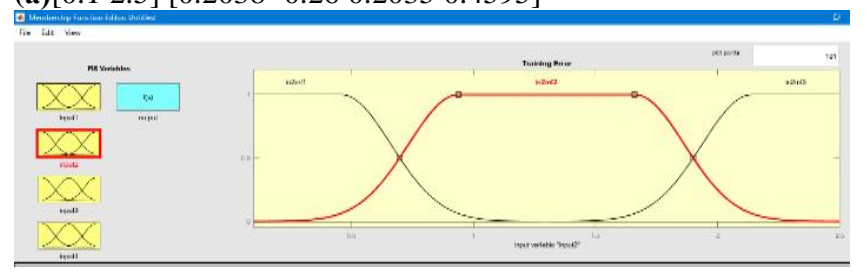

(b) [0.2049 0.93920 .20381 .66$]$

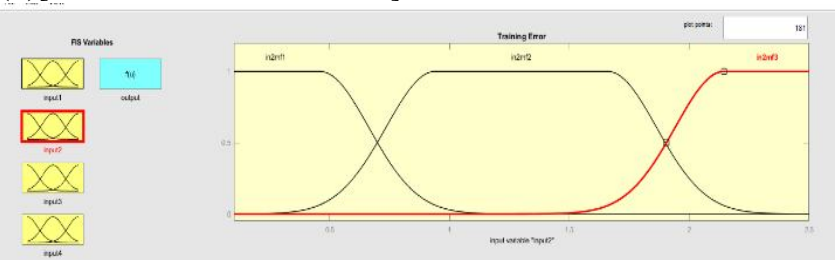

(c)[0.204 2.15 0.204 2.87]

Figure 3: Double Gaussian functions of membership of input parameter $x_{2}$ "resource efficiency" are equal after introduction of the parameters for "high" (a), "average" (b), "low" (c) terms

$$
\begin{gathered}
\mu_{\text {high }}\left(x_{2}\right)=\left\{\begin{array}{c}
e^{-\frac{1}{2}\left(\frac{x_{2}-2,15}{0,204}\right)^{2}}, \text { if } x_{2} \leq 2,15 \\
1, \text { if } x_{2}>2,15
\end{array}\right. \\
\mu_{\text {av }}\left(x_{2}\right)=\left\{\begin{array}{c}
e^{-\frac{1}{2}\left(\frac{x_{2}-0,9392}{0,2049}\right)^{2}}, \text { if } x_{2} \leq 0,939 \\
1, \text { if } 0,939<x_{2}<1,66 \\
e^{-\frac{1}{2}\left(\frac{x_{2}-1,66}{0,2038}\right)^{2}}, \text { if } x_{2} \geq 1,66
\end{array}\right. \\
\mu_{\text {low }}\left(x_{2}\right)=\left\{\begin{array}{c}
e^{-\frac{1}{2}\left(\frac{x_{2}-0,4595}{0,2035}\right)^{2}}, \text { if } x_{2} \geq 0,4595 \\
1, \text { if } x_{2}<0,4595
\end{array}\right.
\end{gathered}
$$

The membership functions for "rigid price policy", "moderate price policy" and "flexible price policy" terms are presented on the curve (figure $4 \mathrm{a}-\mathrm{c}$ ). As one can see on figure 4 , the tender offer value diminution level of the analyzed companies made up from 0 to $31 \%$. 
A level of diminution of prices by less than $4 \%$ is considered rigid price policy, because parameter $\mathrm{B}_{1}=0,03972$. That is the contractors, who diminish the values of tender offers by less than $4 \%$ upon the average, definitely keep to rigid price policy. Moderate price policy is conducted, when the discount level is from 10,8 to $20 \%$, and indisputably flexible policy is conducted, when the level of diminution is more than $25,48 \%$.

$$
\begin{gathered}
\mu_{\text {rig }}\left(x_{3}\right)=\left\{\begin{array}{c}
e^{-\frac{1}{2}\left(\frac{x_{3}-0,13}{0,03972}\right)^{2}}, \text { if } x_{3}>0,13 \\
1, \text { if } x_{3} \leq 0,13
\end{array}\right. \\
\mu_{\text {mod }}\left(x_{3}\right)=\left\{\begin{array}{c}
e^{-\frac{1}{2}\left(\frac{x_{3}-0,108}{0,0199}\right)^{2}}, \text { if } x_{3} \leq 0,108 \\
1, \text { if } 0,108<x_{3}<0,2 \\
e^{-\frac{1}{2}\left(\frac{x_{3}-0,2}{0,025}\right)^{2}}, \text { if } x_{3} \geq 0,2
\end{array}\right. \\
\mu_{\text {flex }}\left(x_{3}\right)=\left\{\begin{array}{c}
e^{-\frac{1}{2}\left(\frac{x_{3}-0,2548}{0,04141}\right)^{2}}, \text { if } x_{3} \leq 0,2548 \\
1, \text { if } x_{3}>0,2548
\end{array}\right.
\end{gathered}
$$

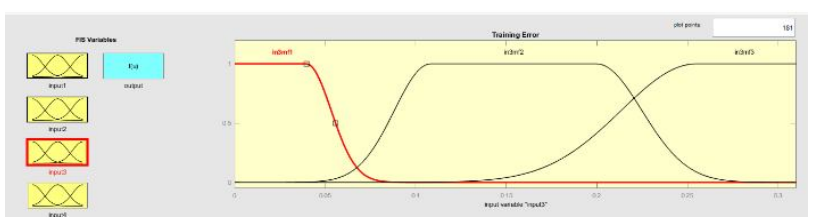

(a) $\left[\begin{array}{llll}0.02633 & -0.0465 & 0.01365 & 0.03972\end{array}\right]$

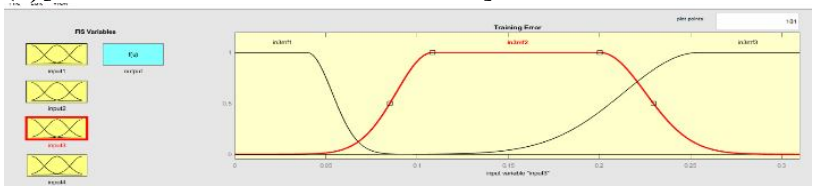

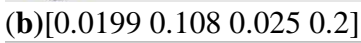

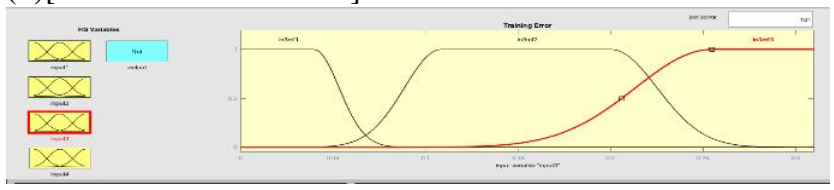

(c) $\left[\begin{array}{lllll}0.04141 & 0.2548 & 0.02633 & 0.3565\end{array}\right]$

Figure 4: Double Gaussian membership functions of input parameter $x_{3}$ "price policy" after introduction of the parameters for "rigid" (a), "moderate" (b) and "flexible" (c) terms

The level of business assurance-reputation of a company in the previous period made up from 0 to 1 among the analyzed companies (figure 5). We are absolutely sure, that companies have a low level of business assurance-reputation, if the percentage of the executed contracts made up less than $14.8 \%$, moderate $-35-65 \%$ and high $-84.9 \%$ in the previous period.
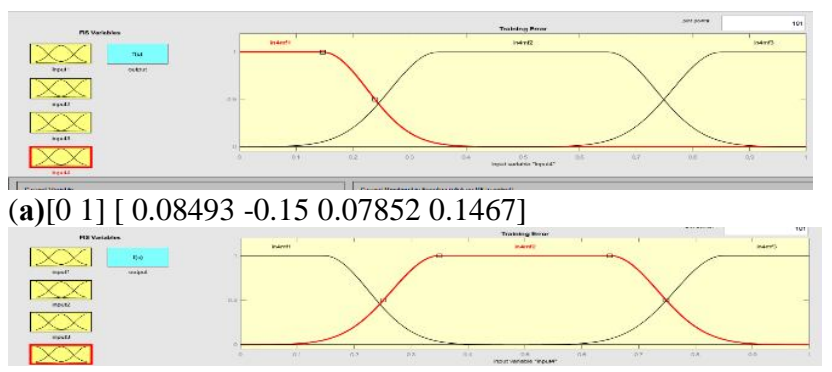

(b) $\left[\begin{array}{llll}0.08374 & 0.35 & 0.08422 & 0.6493\end{array}\right]$

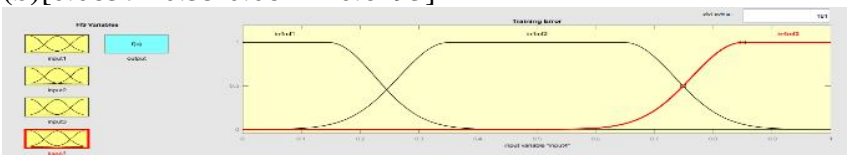

(c) $\left[\begin{array}{llll}0.0854 & 0.849 & 0.0849 & 1.15\end{array}\right]$

Figure 5: Membership functions of input parameter $x_{4}$ "reputation component" after introduction of the parameters for "high level" (a), "average level" (b) and "low level" (c) terms

$$
\begin{aligned}
& \mu_{\text {high }}\left(x_{4}\right)=\left\{\begin{array}{c}
e^{-\frac{1}{2}\left(\frac{x_{4}-0,849}{0,0854}\right)^{2}}, \text { if } x_{4} \leq 0,849 \\
1, \text { if } x_{4}>0,849
\end{array}\right. \\
& \mu_{\text {av }}\left(x_{4}\right)=\left\{\begin{array}{c}
e^{-\frac{1}{2}\left(\frac{x_{4}-0,35}{0,08074}\right)^{2}}, \text { if } x_{4} \leq 0,35 \\
1, \text { if } 0,35<x_{4}<0,6493 \\
e^{-\frac{1}{2}\left(\frac{x_{4}-0,6493}{0,08422}\right)^{2}}, \text { if } x_{4} \geq 0,6493
\end{array}\right. \\
& \mu_{\text {low }}\left(x_{4}\right)=\left\{\begin{array}{c}
e^{-\frac{1}{2}\left(\frac{x_{4}-0,1467}{0,07852}\right)^{2}}, \text { if } x_{4} \geq 0,1467 \\
1, \text { if } x_{4}<0,1467
\end{array}\right.
\end{aligned}
$$

By default, the Anfis-editor add-on of MatLab environment develops and tests fuzzy conclusion algorithms with rules, in which the combination of the input variables terms is a full set of all possible combinations of membership functions of an input variable in the designed Sugeno system - constants. Their substantiation will be presented in combination with the description of the base of rules of fuzzy logical conclusion (figure 6).

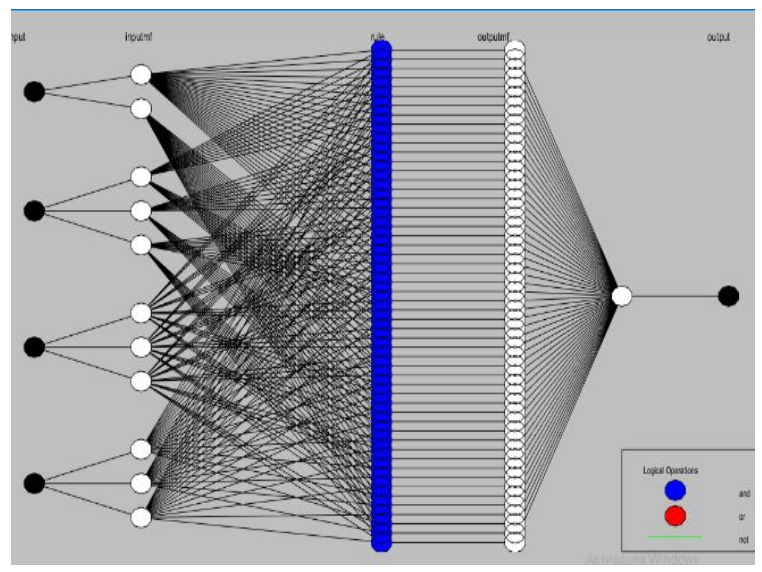

Figure 6: Base of rules of fuzzy logical conclusion

Because the system has three input variables, each of which has three terms and one variable has two terms, the maximal quantity of rules in the knowledge base for formulation of all possible dependencies between the factors and the outcomes can be $2 \times 3^{3}=54$. But not all the rules are necessary for adequate representation of dependency between the inputs and outputs.

According to the information, which is presented in the Rule Editor dialogue window, the rules in the knowledge base have influence equal to 1 . 
These thirteen rules represent the main theses of an arbitrary or forced strategy of formation of financing sources of a contracting building company.

The rules are as follows:

1. If a contractor has a high level of activity concentration, high resource efficiency, if it conduxcts flexible price policy and has high reputation, then the competitiveness level id determined according to $\mathrm{mf} 1$.

2. If activity is concentrated, the resource efficiency is high, the price policy is moderate and the reputation factor level is high, the competitiveness of a contracting company will approach $\mathrm{mf} 3$.

3. If activity is concentrated, the price policy is flexible, the resource efficiency is high and the reputation factor level is low, the competitiveness of a contracting company will approach $\mathrm{mf} 12$.

Influence of the activities concentration and resource efficiency onto the competitiveness of a contractor is shown on figure 4 in the form of spatial surface.
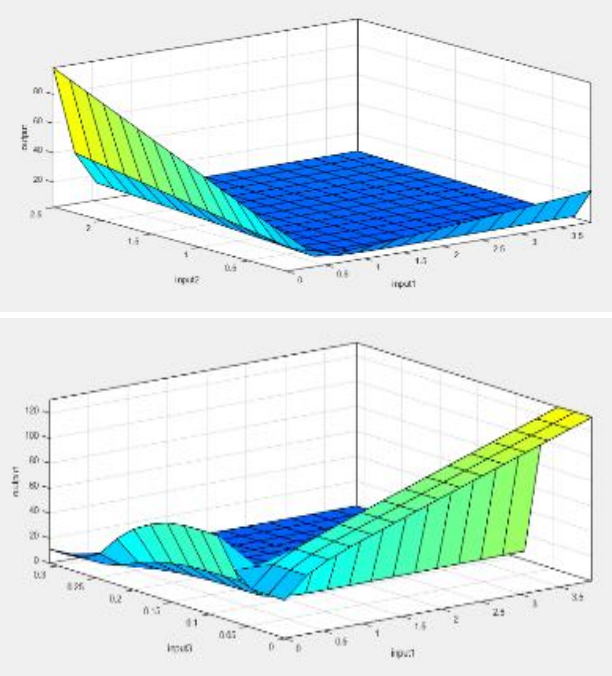

Figure 7: Influence of parameters $x_{1} \mathrm{i} x_{2}$ (a) and $x_{1}$ i $x_{3}$ (b) onto the resulting indicator $y$

Diversification will help raise the company competitiveness, if the resource efficiency is low. If the resource efficiency of a contractor is low, significant growth of competitiveness is possible on condition of diversification of activities, but this dependency does not effect, if the resource efficiency level is sufficient. When the resource efficiency level is higher than the average, the competitiveness of a company stays at a stable level independently from the activity concentration level. If contracting companies conduct rigid price policy, they should broaden their activities in order to strengthen their competitiveness. If they conduct flexible price policy, on the contrary - the competitiveness of contractors rises, if their activity is concentrated in one or several segments, but diversification, on the contrary, does not allow growth of competitive positions. If activities are concentrated, moderate price policy is optimal (discounts from 11 to $23 \%$ ), then the highest growth of competitiveness is achieved.

Five curves were built for each of the seven rules in the designed algorithm, four of which meet the input variables $x_{1}-x_{4}$, and one output $-y$. The results of activization of the rules, which have a degree of trueness higher than zero, are shown in yellow colour, and for the output variable - with dark-blue. If a membership function has zero trueness, then colour is absent on the curve. One more resulting curve is placed after all the curves of the output variable. The exact value of the output is determined specifically according to it.

The degree of trueness of the conclusion of each of the rules of the knowledge base is determined on the basis of trueness of their preconditions at the second stage "logical conclusion".

Provision of a contractor competitiveness is possible on condition of achievement of all the four conditions, which are, however, uneven between themselves. Simultaneous satisfaction of the preconditions of several rules of fuzzy sets is determined by means of the minimum operation in the fuzzy sets theory. That is the competitive potential of a contractor will correspond to the minimal value of mathematical expectation of fulfillment of each of the conditions.

The significance of specific conditions is considered by means of their concentration, which is calculated by raising of a specific membership function to a degree equal to the significance of the rule-condition $\left(w_{j}\right)$. That is the minimal value of all the three membership functions determines to what degree the current competitiveness of a company corresponds to its goal value:

$$
\begin{aligned}
& \mu_{\text {конкур }}=\left(\mu_{\text {необх }}\left(\mathrm{x}_{1}\right)\right)^{\omega_{1}} \wedge\left(\mu_{\text {необх }}\left(\mathrm{x}_{2}\right)\right)^{\omega_{2}} \wedge\left(\mu_{\text {необх }}\left(\mathrm{x}_{3}\right)\right)^{\omega_{3}} \wedge\left(\mu_{\text {необх }}\left(\mathrm{x}_{4}\right)\right)^{\omega_{4}} \\
& \mu_{\text {конкур }}=\min \left(\left(\mu_{\text {необх }}\left(\mathrm{x}_{1}\right)\right)^{\omega_{1}} ;\left(\mu_{\text {необх }}\left(\mathrm{x}_{2}\right)\right)^{\omega_{2}}\left(\mu_{\text {необх }}\left(\mathrm{x}_{3}\right)\right)^{\omega_{3}} ;\left(\mu_{\text {необх }}\left(\mathrm{x}_{4}\right)\right)^{\omega_{4}}\right)
\end{aligned}
$$

The result of the formula is in fractions of unity. That is the degree of correspondence of the current level of competitiveness to the requirements of stable development can be used as a lowering coefficient, when calculating money flows from various activities of contracting companies.

\section{RESULTS AND DISCUSSION}

A system of indicators, which can serve as indices of the high level of the stable development potential of contracting building companies was discovered, among which growth of a market share, financial stability may be distinguished. This system was supplemented with the indicator subgroups: concentration-diversification of activities, level of market assurance. The factors, which form the competitiveness of contracting companies, are business assurance, financial stability, resource efficiency and price policy flexibility. the supplemented classification provides better substantiation of solutions, which concern management of development of building companies, and it can be taken as a basis for goal-oriented management of the competitiveness of both developer and contracting companies. 
Sergii Stetsenko et al., International Journal of Emerging Trends in Engineering Research, 9(2), February 2021, 60 - 65

\section{CONCLUSION}

It is suggested to accomplish evaluation of the level of ability of contracting companies to keep and improve their competitive positions using a hierarchical Sugeno-type algorithm on the basis of input variables, activity level concentration, resource efficiency, price policy flexibility and business assurance level, which would allow to form the competitive policy of a contractor with substantiation and orientation at goals in middle and long-term perspectives. The offered system of evaluation of competitiveness of a contracting company allows to distinguish factors, which are key ones for provision of stable development, and to influence them, while forming this way competitive advantages in the long-term perspective.

\section{REFERENCES}

1. R. Ya. Zeltser, O. Yu. Bielienkova, Ye. Novak and D. V. Dubinin. Digital Transformation of Resource Logistics and Organizational and Structural Support of Construction, Nauka i innovatsii, Vol. 15(5), 2019, pp. 38-51

2. S. P. Stetsenko, V. V. Tytok, O. M. Emelianova, O. Yu. Bielienkova and T. Yu. Tsyfra. Management of Adaptation of Organizational and Economic Mechanisms of Construction to Increasing Impact of Digital Technologies on the National Economy, Journal of Reviews on Global Economic, 2020, № 9, pp. 149-164.

DOI: https://doi.org/10.6000/1929-7092.2020.09.15

3. S. Stetsenko, N. Bolila, L. Sorokina, T. Tsyfra and O. Molodid. Monitoring mechanism of resilience of the anti-crisis potential system of the construction enterprise in the long-term period. Economics, Finance and Management Review, № 3, 2020, pp. 29-40. https://doi.org/10.36690/2674-5208-2020-3-29.

4. T. Tsyfra, N. Bolila and O. Molodid. Theoretical basis of formation of economic immunity of construction companies, Shliakhy pidvyshchennia efektyvnosti budivnytstva $v$ umovakh formuvannia rynkovykh vidnosyn, Issue 38, 2018, pp. 276 - 282. (in Ukrainian).

5. O. Yu. Bielienkova. Stratehiya ta mekhanizmy zabezpechennya konkurentospromozhnosti budivel'nykh pidpryyemstv na osnovi modeli staloho rozvytku. [Strategy and mechanisms for ensuring the competitiveness of construction companies based on the model of sustainable development]. Kyiv, Lira-K, 2020. 512 p. (in Ukrainian)

6. O. Yu. Bielienkova. Vdoskonalennya mekhanizmu upravlinnya konkurentnym potentsialom developera zasobamy shtuchnoho intelektu. [Improving the mechanism of managing the competitive potential of the developer by means of artificial intelligence], Actual problems of economics. № 3, 2020, pp. 107-122. (in Ukrainian).
7. O. A. Tugai, P. Ye. Hryhorovskyi, V. O. Khyzhniak, S. P. Stetsenko, O. Yu. Bielienkova, O. S. Molodid and D. O. Chernyshev. Organizational and technological, economic quality control aspects in the construction industry. Lviv-Toruń, Liha-Pres, 2019, pp. 77-93.

8. O. Bielienkova, S. Stetsenko, L. Sorokina, O. Molodid and N. Bolila. System of preventive action of construction enterprises on the basis of identification of anticrisis potential, Scientific Journal of Astana IT University, №3, 2020, pp. 15-27. DOI: 10.37943/AITU.2020.53.13.002

9. T. Honcharenko, Y. Chupryna, I. Ivakhnenko, M. Zinchenco, T. Tsyfra. Reengineering of the Construction Companies Based on BIM-technology, International Journal of Emerging Trends in Engineering Research, 8(8), August 2020, pp. 4166-4172

https://doi.org/10.30534/ijeter/2020/22882020

10. J. Marchuk, D Ryzhakov, G. Ryzhakova, S. Stetsenko. Identification of the basic elements of the innovation-analytical platform for energy efficiency in project financing, Investment Management and Financial Innovations, Vol. 14, Issue 4, 2017, pp. 12-20, http://dx.doi.org/10.21511/imfi.14(4).2017.02

11. K. I. Kyivska, S. V. Tsiutsiura, M. I. Tsiutsiura, O. V. Kryvoruchko, A. V. Yerukaiev and V. V. Hots. A study of the concept of parametric modeling of construction objects, International Journal of Advanced Research in Engineering and Technology, Volume 10, Issue 2, 2019, pp 636-646.

12. A. G. Myasnikov. Information and logical modeling in construction, International Journal of Advanced Trends in Computer Science and Engineering, 9(1), January -February 2020, pp. 304-307, https://doi.org/10.30534/ijatcse/2020/46912020.

13. D. Ryzhakov, O. Dikiy, M. Druzhynin, H. Petrenko and T. Savchuk. Innovative tools for management the lifecycle of strategic objectives of the enterprise-stakeholder in construction, International Journal on Emerging Trends in Engineering Research, $8(8), \quad 2020, \quad$ pp. 4526-4532, https://doi.org/10.30534/ijeter/2020/78882020.

14. D. Chernyshev, D. Ryzhakov, O. Dikiy, O. Khomenko and S. Petrukha. Innovative Technology for Management Tools of Commercial Real Estate in Construction, International Journal on Emerging Trends in Engineering Research, 8(9), September 2020, pp. 4967-4973, https://doi.org/10.30534/ijeter/2020/13892020

15. G. Ryzhakova, V. Pokolenko, O. Malykhina, K. Predun and N. Petrukha. Structural Regulation of Methodological Management Approaches and Applied Reengineering Tools for Enterprises-Developers in Construction, International Journal of Emerging Trends in Engineering Research, $8(10), \quad$ pp. $\quad 7560-7567, \quad$ October 2020. https://doi.org/10.30534/ijeter/2020/1428102020. 